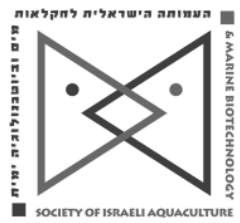

The IJA appears exclusively as a peerreviewed on-line Open Access journal at http://www.siamb.org.il Sale of IJA papers is strictly forbidden.

\title{
The Effects of Different Carotenoid Sources on Skin Pigmentation of Goldfish (Carassius auratus)
}

\section{Nihat Yeşilayer ${ }^{1 *}$, Orhan Aral ${ }^{2}$, Zafer Karsli ${ }^{2}$, Meryem Öz ${ }^{2}$, Ali Karaçuha $^{2}$, Feraye Yağci ${ }^{3}$}

${ }^{1}$ Department of Aquaculture, Faculty of Agriculture, Gaziosmanpaşa University, Tokat, Turkey

${ }^{2}$ Departments of Aquaculture, Sinop Faculty of Fisheries, University of Sinop, Sinop, Turkey

${ }^{3}$ Sibal Fish Feed Manufacture, Turkey

(Received 12.1.10, Accepted 12.2.10)

Key words: goldfish, pigmentation, Oleoresin paprika, Gammarus spp., astaxanthin, canthaxanthin, colorimetric analysis

\begin{abstract}
The aim of this study was to investigate the effect of different carotenoid sources on goldfish (Carassius auratus) skin pigmentation. The value of goldfish depends on the intensity of the skin color. In the red variety of goldfish, an orange-red hue is desirable. Juvenile goldfish were fed one of five diets for five months to determine the effects of carotenoids on skin pigmentation, growth, feed efficiency, and survival: (1) astaxanthin (carophyll pink at $75 \mathrm{mg} / \mathrm{kg}$ ), (2) canthaxanthin (carophyll red at $75 \mathrm{mg} / \mathrm{kg}$ ), (3) Gammarus spp. (75 mg/kg), (4) Oleoresin paprika (180 mg/kg), and (5) an unsupplemented control. Growth and feed efficiency did not significantly differ among groups. Initial and final samples of head skin were measured by colorimetric analysis for lightness $\left(L^{*}\right)$, redness $\left(a^{*}\right)$, yellowness $\left(b^{*}\right)$, hue $\left(\mathrm{H}^{\circ} a b\right)$, and chroma $\left(\mathrm{C}_{a b} *\right)$. The best red color (a* and $\mathrm{H}_{\mathrm{ab}}$ ) was obtained with the astaxanthin, canthaxanthin, and paprika diets.
\end{abstract}

* Corresponding author. Tel.: +90-356-2521616/2278, e-mail: nihatyesilayer@gmail.com 


\section{Introduction}

Goldfish (Carassius auratus) are among the most valuable and desired fish in the ornamental trade. In highly-valued ornamental species such as goldfish, emphasis is given to skin pigmentation which, together with body shape, fin shape, double-split caudal fin, and body size, are the most important criteria that determine market value. Fish, like other animals, are unable to perform de novo synthesis of carotenoids and therefore rely on dietary supply for natural pigmentation. Fish reared in intensive rearing conditions are fed compound feeds which must be supplemented with carotenoids. Synthetic astaxanthin and canthaxanthin are widely used as supplements in diets for salmonids to induce the desired pink flesh.

Given the high costs of synthetic colorings, natural compounds such as those obtained from the red yeast Phaffia rhodozyma (Bon et al., 1997), the marine bacteria Agrobacterium aurantiacum (Yokoyama and Miki, 1995), the green algae Haematococcus pluvialis (Harker et al., 1996), and Chlorella vulgaris (Gouveia et al., 1996) have been evaluated as sources of dietary carotenoids. In addition, Oleoresin paprika, red pepper (Capsicum annum), marigold flower (Tagetes erecta), Dunaliella, Spirulina, krill, and crustacean meals have rich and abundant carotenoid pigments and could be considered as alternative sources (Vernon-Carter et al., 1994, 1996; Akhtar et al., 1999). Goldfish and fancy red carp accumulate capsanthin, which is contained in large amounts in red paprika, and oxidatively metabolize it to 4ketocapsanthin, an effect that increases remarkably in sunlight (Tsushima et al., 1999).

Fish farmers need a simple, rapid, and accurate method for analyzing color. Although there are several methods to assess color, reflectance spectroscopy measurement of parameters based on tristimulus values of lightness $\left(L^{*}\right)$, redness (a*), and yellowness $\left(b^{*}\right)$ is a direct and increasingly popular technique. Such instrumental measurements are more precise, objective, and less subject to variations resulting from differences in light conditions than other methods.

The aim of the present study was to investigate the effect of two natural (oleoresin paprika and Gammarus spp.) and two synthetic (astaxanthin and canthaxanthin) carotenoid sources on skin pigmentation, growth, feed utilization, and survival of juvenile goldfish.

\section{Materials and Methods}

The experiment was conducted at the Fresh Water Fish Farming Unit of the Sinop Faculty of Fisheries in Ondokuz Mayis University (Sinop, Turkey).

Diets and carotenoid sources. Fish were fed one of five diets: unsupplemented control, astaxanthin, canthaxanthin, Gammarus, or oleoresin paprika. The basal control diet contained $340 \mathrm{~g} / \mathrm{kg}$ crude protein and $150 \mathrm{~g} / \mathrm{kg}$ fat, without the added colorings (Table 1 ). Using this basal mixture, four other diets were formulated that contained $75 \mathrm{mg} / \mathrm{kg}$ astaxanthin (Carophyll ${ }^{\circledR}$ pink $8 \%$, DSM, Basel, Switzerland), canthaxanthin (Carophyll ${ }^{\circledR}$ red $10 \%, \mathrm{DSM}$, Basel, Switzerland), or Gammarus, or $180 \mathrm{mg} / \mathrm{kg}$ Oleoresin paprika. The 
synthetic astaxanthin and canthaxanthin were in the form of water-dispersible beadlets.

The dry feed materials were screened through a 500- $\mu \mathrm{m}$ sieve, weighed separately, and mixed with the oil in a blender for $15 \mathrm{~min}$. Oleoresin paprika was blended together with the dry ingredients and the oil. The synthetic carotenoids were dissolved in water at $60-70^{\circ} \mathrm{C}$ and added to the mixture after blending. The diets were dried to a moisture content of $92-95 \mathrm{~g} / \mathrm{kg}$ in an oven and stored at $-20^{\circ} \mathrm{C}$, protected from light, throughout the experiment.

The chemical composition of the diets was determined according to AOAC (1984) guidelines as follows: dry matter after drying at $105^{\circ} \mathrm{C}$ for $24 \mathrm{~h}$, ash by combustion at $550^{\circ} \mathrm{C}$ for $12 \mathrm{~h}$, crude protein $(\mathrm{N} \times 6.25)$ by the $\mathrm{Kjeldahl}$ method after acid digestion, and crude lipid by ethyl extraction in a Soxhlet System; nitrogen free extracts was calculated by difference.

Table 1. Proximate composition $(\mathrm{g} / \mathrm{kg})$ of experimental diets.

\begin{tabular}{|c|c|c|c|c|c|}
\hline & \multicolumn{5}{|c|}{ Diet } \\
\hline & Control & Astaxanthin $^{1}$ & Cantahaxanthin ${ }^{2}$ & Gammarus & Oleoresin paprika ${ }^{3}$ \\
\hline Moisture & 75.80 & 56.20 & 45.10 & 77.20 & 62.90 \\
\hline Crude protein & 342.35 & 339.04 & 338.22 & 325.23 & 337.30 \\
\hline Crude lipid & 153.14 & 148.23 & 146.98 & 149.01 & 185.12 \\
\hline Crude ash & 87.80 & 102.70 & 88.30 & 88.90 & 86.00 \\
\hline Nitrogen-free extracts ${ }^{4}$ & 340.91 & 353.83 & 380.08 & 367.76 & 328.68 \\
\hline Gross energy $(\mathrm{kcal} / \mathrm{g})^{5}$ & 4779 & 4767 & 4858 & 4754 & 5003 \\
\hline
\end{tabular}

${ }^{1}$ Astaxanthin: CarophylI ${ }^{\circledR}$ pink (8\%), DSM, Basel, Switzerland

${ }^{2}$ Canthaxanthin: Carophy $1{ }^{\circledR}$ red $(10 \%)$, DSM, Basel, Switzerland

${ }^{3}$ Oleoresin paprika extract: Aromeks, Istanbul, Turkey

${ }^{4}$ Nitrogen-free extracts $=100$ - (\%crude protein $+\%$ crude lipids $+\%$ crude ash $+\%$ crude cellulose)

${ }^{5}$ Calculated according to $5.65 \mathrm{kcal} / \mathrm{g}$ protein, $9.45 \mathrm{kcal} / \mathrm{g} \mathrm{lipid,} 4.1 \mathrm{kcal} / \mathrm{g}$ nitrogen free extract

The AOAC spectrophotometer analysis method was used to analyze total carotenoids. To minimize losses due to isomerization or auto-oxidation, absorbance measurements were performed as quickly as possible in a spectrophotometer (Jasco-V-530 UV/VIS spectrophotometer) with the wavelength adjusted to $460 \mathrm{~nm}$. To determine the percent carotenoid in the feed, the extraction coefficient was E\% $1.1 \mathrm{~cm}=1922$ for acetone and E\% 1.1 $\mathrm{cm}=1900$ for astaxanthin and canthaxanthin (Skrede and Storebakken 1986; Skrede et al. 1989).

Fish and rearing conditions. Juvenile goldfish (Carassius auratus) were obtained from the experimental fish farm at the Fresh Water Fish Farming Unit of the Faculty of Fisheries in Sinop University. Homogeneous groups of 15 5-month-old goldfish $(0.1 \mathrm{~g})$ were randomly distributed into 15 (three replicates of each treatment) 12-I rectangular plastic tanks that were continually aerated by air pumps. Dissolved oxygen ranged $8-10 \mathrm{mg} / \mathrm{l}$, water temperature was maintained at a mean of $22^{\circ} \mathrm{C}$ with water heaters, and lighting consisted of the natural photoperiod ( $14 \mathrm{~h}$ light:10 $\mathrm{h}$ dark). Daily water exchange was $30 \%$. Fish were fed by hand ad libitum (until uneaten 
feed was visible) twice a day (9:00 and 18:00) for 144 days and the daily feed intake was recorded. Tanks were cleaned daily to remove uneaten feed and fecal material. Fish were weighed at the start of the experiment, at the beginning of each month, and at the end of the experiment. Fish were deprived of feed for one day prior to weighing. At the end of experiment, three fish from each group were sampled for colorimetric analysis.

Color and carotenoid assessment. Colorimetric measurements were conducted at the Food Engineering Laboratory of the Faculty of Agriculture at Gaziosmanpaşa University. Fish samples were assessed instrumentally using a Tristimulus Colorimeter (Minolta Chroma Meter, CR-300 Minolta, Osaka, Japan) which measured light reflection from the head section (red region) of the fish in comparison to a standard calibration plate. Measured color parameters were lightness $\left(L^{*}\right)$ which varies from 100 for perfect white to 0 for black, and chromaticity where a* measures redness when positive, grey when zero, and greenness when negative and $b^{*}$ measures yellowness when positive, grey when zero, and blueness when negative (CIE, 1976).

Three fish from each tank (nine from each treatment) were taken for colorimetric analysis. One red spot on the head of each fish was measured. Hue $\left(\mathrm{H}^{\circ}\right.$ ab), which expresses the relationship between the redness and the yellowness of the skin, is an angular measurement where $0^{\circ}$ indicates a red hue and $90^{\circ}$ indicates a yellow hue (Hunt, 1977). Hue was calculated as $\mathrm{H}^{\circ}{ }_{\mathrm{ab}}$ $=\tan ^{-1}\left(b^{*} / a^{*}\right)$ when $a^{*}>0^{\circ}$ or $\mathrm{H}^{\circ}{ }_{a b}=180+\tan ^{-1}\left(b^{*} / a^{*}\right)$ when $a^{*}<0^{\circ}$. Chroma $\left(\mathrm{C}_{\mathrm{ab}}{ }^{*}\right)$, which expresses the intensity and clarity of the color, was calculated as $\mathrm{C}_{\mathrm{ab}} *=\left(\mathrm{a}^{2}+\mathrm{b}^{* 2}\right)^{1 / 2}$.

Statistical analysis. Data on growth, feed conversion ratio, survival, and skin color are expressed as means \pm standard error. Data from each treatment for each sampling were analyzed by one-way ANOVA, and significant differences (if present) were ranked with Tukey's multiple comparison test at the $5 \%$ level of significance by using the MINITAB Release 13.1 Statistical Analysis Software Program for Windows, Version 10.0.1 (Minitab Inc., Chicago, Illinois, USA).

\section{Results}

All diets were equally consumed by the fish. There were no significant differences in mean final weight, weight gain, or specific growth rate (Table 2). There were also no significant differences in feed conversion ratio. The Gammarus and canthaxanthin groups survived at a significantly higher rate than those the other groups $(p<0.05)$.

Color intensity $\left(L^{*}\right)$ of goldfish fed the control and Gammarus diets was significantly stronger than that of groups fed other diets (Table 3 ). The weakest color intensity was obtained in the group fed the diet containing canthaxanthin.

The a* (red pigment) values of fish fed diets containing astaxanthin, canthaxanthin, or paprika were significantly higher than those of the control, Gammarus diet, and initial value. There was a significant increase in a* value of all fish fed diets containing carotenoid. Likewise, the yellow pigment $\left(b^{*}\right)$ increased in all groups fed diets containing carotenoids. The hue $\left(\mathrm{H}^{\circ}{ }_{a b}\right)$ 
Table 2. Weight gains and growth factors in goldfish fed diets containing different sources of carotenoids.

\begin{tabular}{lccccc}
\hline & Control & Astaxanthin & Canthaxanthin & Gammarus & $\begin{array}{c}\text { Oleoresin } \\
\text { paprika }\end{array}$ \\
\hline Initial wt (g) & $0.10 \pm 0.006$ & $0.10 \pm 0.006$ & $0.10 \pm 0.006$ & $0.10 \pm 0.01$ & $0.10 \pm 0.06$ \\
Final wt (g) & $1.03 \pm 0.091$ & $1.06 \pm 0.083$ & $1.01 \pm 0.06$ & $0.89 \pm 0.07$ & $1.11 \pm 0.14$ \\
Weight gain (g) & $0.93 \pm 0.086$ & $0.96 \pm 0.055$ & $0.91 \pm 0.006$ & $0.79 \pm 0.003$ & $1.01 \pm 0.02$ \\
Weight gain (\%) & $926.60 \pm 84$ & $956.70 \pm 55.2$ & $904.50 \pm 57.3$ & $791.3 \pm 3.18$ & $1011 \pm 24.2$ \\
$\begin{array}{l}\text { Specific growth } \\
\text { rate (\%/day) }\end{array}$ & $1.61 \pm 0.06$ & $1.64 \pm 0.04$ & $1.60 \pm 0.04$ & $1.52 \pm 0.00$ & $1.67 \pm 0.02$ \\
$\begin{array}{l}\text { Feed conversion } \\
\text { ratio }\end{array}$ & $2.39 \pm 0.035$ & $2.01 \pm 0.072$ & $2.10 \pm 0.198$ & $2.27 \pm 0.02$ & $2.15 \pm 0.08$ \\
Survival (\%) & $77.78 \pm 2.22^{\mathrm{a}}$ & $88.89 \pm 4.45^{\mathrm{ab}}$ & $97.78 \pm 2.22^{\mathrm{b}}$ & $100 \pm 0.00^{\mathrm{b}}$ & $82.22 \pm 4.45^{\mathrm{a}}$ \\
\hline Values in
\end{tabular}

Values in the same row with different superscripts significantly differ (one-way ANOVA and Tukey's multiple-range test; $p<0.05$ ).

dropped in all groups fed diets containing carotenoids. Chroma $\left(\mathrm{C}_{\mathrm{ab}} *\right)$ increased throughout the experiment in groups fed pigmented feed. Although the highest value was obtained in the paprika group, it did not significantly differ from the groups fed synthetic astaxanthin.

Table 3. Color measurements in skin of juvenile Carassius auratus fed diets containing carotenoids of different sources for five months.

\begin{tabular}{lcccccc}
\hline \multirow{2}{*}{ Color } & \multirow{2}{*}{ Initial } & \multicolumn{5}{c}{ End of experiment } \\
\cline { 3 - 6 } & & Control & Astaxanthin & Canthaxanthin & Gammarus & Oleoresin paprika \\
\hline $\mathrm{L}^{*}$ & $75.48 \pm 0.91^{\mathrm{a}}$ & $72.62 \pm 0.73^{\mathrm{ab}}$ & $68.79 \pm 1.02^{\mathrm{b}}$ & $62.93 \pm 1.51^{\mathrm{c}}$ & $74.86 \pm 0.91^{\mathrm{a}}$ & $68.99 \pm 2.07^{\mathrm{b}}$ \\
$\mathrm{a}^{*}$ & $1.22 \pm 0.20^{\mathrm{a}}$ & $2.13 \pm 0.29^{\mathrm{a}}$ & $6.05 \pm 0.27^{\mathrm{b}}$ & $7.72 \pm 0.64^{\mathrm{b}}$ & $2.69 \pm 0.39^{\mathrm{a}}$ & $6.19 \pm 0.66^{\mathrm{b}}$ \\
$\mathrm{b}^{*}$ & $15.07 \pm 0.54^{\mathrm{a}}$ & $15.49 \pm 0.64^{\mathrm{a}}$ & $19.98 \pm 1.07^{\mathrm{bc}}$ & $17.87 \pm 0.91^{\mathrm{ab}}$ & $16.28 \pm 0.64^{\mathrm{ab}}$ & $23.16 \pm 2.00^{\mathrm{c}}$ \\
$\mathrm{H}^{\mathrm{O}}{ }_{\mathrm{ab}}$ & $85.44 \pm 0.67^{\mathrm{a}}$ & $82.14 \pm 0.95^{\mathrm{a}}$ & $72.96 \pm 0.88^{\mathrm{b}}$ & $66.57 \pm 1.62^{\mathrm{c}}$ & $80.62 \pm 1.34^{\mathrm{a}}$ & $73.88 \pm 2.61^{\mathrm{b}}$ \\
$\mathrm{C}_{\mathrm{ab}}{ }^{\mathrm{b}}$ & $15.13 \pm 0.55^{\mathrm{a}}$ & $15.65 \pm 0.65^{\mathrm{ab}}$ & $20.90 \pm 1.05^{\mathrm{cd}}$ & $19.53 \pm 0.96^{\mathrm{bc}}$ & $16.54 \pm 0.65^{\mathrm{ab}}$ & $24.15 \pm 1.81^{\mathrm{d}}$ \\
\hline
\end{tabular}

Values in the same row with different superscripts significantly differ (one-way ANOVA and Tukey's multiple-range test; $p<0.05$ ).

\section{Discussion}

Carotenoids have a positive role in the intermediary metabolism of fish (Tacon, 1981) that could enhance nutrient utilization and ultimately result in improved growth (Amar et al., 2001). Carotenoids are widely used as dietary supplements in diets for salmonids as a method for inducing pink color in the flesh (Torrissen, 1995). Besides their effectiveness in pigmentation of fish skin, carotenoids have a positive effect on the nutrition of larvae and survival of young fry (Shahidi et al., 1998). In the present study, growth and FCR did not differ from the control in groups fed supplementary carotenoids. Although these results are in accordance with some studies carried out with juvenile goldfish (Paripatananont et al., 1999; Gouveia et al., 2003; Hancz et al., 2003; Gouveia and Rema, 2005; Xu et al., 2006), not all studies obtained similar results (Wallat et al., 2005). Survival of goldfish fed diets containing 
Gammarus and canthaxanthin was significantly higher than of goldfish fed the other diets. This was not unexpected because carotenoid influences immunity (Miki, 1991). Carotenoid intake affects both humoral and cell-mediated immunity in Atlantic salmon, ultimately producing higher survival rates (Parıpatananont et al., 1999).

After five months of consuming supplemented diets, $\mathrm{L}^{*}$ and $\mathrm{H}^{\circ}$ ab dropped and $a^{*}, b^{*}$, and $\mathrm{C}_{\mathrm{ab}} *$ increased in all groups, similar to results of Skrede and Storebakken (1986), Christiansen et al. (1988), Skrede et al. (1989), Choubert et al. (1992), Nickell and Bromage (1998), and Ingle de la Mora et al. (2006). Variations in the average values of the color parameters can be attributed to three main factors: (a) non-uniform distribution of carotenoids in the tested region, (b) the use too few discrete measurement points on the fish surface, and (c) incident beam reflectance (Skrede and Storebakken 1986; Skrede et al. 1989; Hatlen et al. 1998; Ingle de la Mora et al. 2006).

Astaxanthin, canthaxanthin, and oleoresin paprika definitely imparted head skin pigmentation; the color in groups fed these diets became redder with time. Mean redness values ( $\mathrm{a}^{*}$ and $\mathrm{H}^{\circ}{ }_{\mathrm{ab}}$ angle) in goldfish fed these diets statistically differed from those of the other groups. The a* value generally shows the best relationship with the carotenoid as it increases as the carotenoid content increases (Bjerkeng, 2000). In the present study, the a* value increased from 1.22 at the start of experiment to $6.05,7.72$, and 6.19 at the end of experiment for astaxanthin, canthaxanthin, and oleoresin paprika, respectively. The initial $\mathrm{H}^{\circ}$ ab value was high (85.44) in all treatment groups but, by the end of the feeding period, it was quite low in the astaxanthin (72.96), canthaxanthin (66.57), and oleoresin paprika (73.88) groups. Fish fed the diets containing astaxanthin, canthaxanthin, or oleoresin paprika appeared to change from yellow to red as the experiment progressed.

Yellow hue ( $\left.b^{*}\right)$ improved when goldfish were fed the diet containing oleoresin paprika, perhaps because of its capsanthin content (Akhtar et al., 1999; Ingle de la Mora et al., 2006; Büyükçapar et al., 2007).

Our results indicate that fish were able to efficiently utilize capsanthin from oleoresin paprika. Similar results were obtained for goldfish (Hancz et al., 2003; Wallat et al., 2005) with other natural carotenoid sources such as red yeast (Xu et al., 2006), Spirulina (Kiriratnikom et al., 2005), Chlorella vulgaris, Haematococcus pluvialis, and Arthrospira maxima (Gouveia et al., 2003; Gouveia and Rema, 2005), and alfalfa (Yanar et al., 2008). Our results show that oleoresin paprika was as effective a carotenoid source as synthetic canthaxanthin and astaxanthin. In addition, our results show that canthaxanthin is better synthetic carotenoid source than astaxanthin.

\section{References}

Akhtar P., Gray J.I., Cooper T.H., Garling D.L. and A.M. Booren, 1999. Dietary pigmentation and deposition of a-tocopherol and carotenoids in rainbow trout muscle and liver tissue. J. Food Sci., 64:234-239.

Amar E.C., Kiron V., Satoh, S. and T. Watanabe, 2001. Influence of various dietary synthetic carotenoids on bio-defence mechanisms in rainbow 
trout, Oncorhynchus mykiss (Walbaum). Aquacult. Res., 32(Suppl. 1):162163.

AOAC, 1984. Official Methods for Analysis, 14th ed. Association of Official Analytical Chemists, Washington D.C.

Bjerkeng B., 2000. Carotenoid pigmentation of salmonid fishes - recent progress. pp. 71-89. In: Avances en Nutricion Acuicola V Memorias del V. Simposium Internacional de Nutricion Acuicola. 19-22 November, Merida, Yucatan.

Bon J.A., Leathers T.D. and R.K. Jayaswal, 1997. Isolation of astaxanthinoverproducing mutants of Phaffia rhodozyma. Biotechnol. Lett., 19:109-112.

Büyükçapar H., Yanar M. and Y. Yanar, 2007. Pigmentation of rainbow trout (Oncorhynchus mykiss) with carotenoids from marigold flower (Tagetes erecta) and red pepper (Capsicum annum). Turk J. Vet. Anim. Sci., 31:1-6.

Choubert G. and T. Storebakken, 1989. Dose response to astaxanthin and canthaxanthin pigmentation of rainbow trout fed various dietary carotenoid concentrations. Aquaculture, 81:69-77.

Choubert G., Blanc J. and C. Courvalin, 1992. Muscle carotenoid content and color of farmed rainbow trout fed astaxanthin or canthaxanthin as affected by cooking and smoke-curing procedures. Int. J. Food Sci. Technol., 27: 277-284.

Christiansen J.S. and J.C. Wallace, 1988. Deposition of canthaxanthin and muscle lipid in two size groups of Arctic charr, Salvelinus alpinus (L.). Aquaculture, 69(1-2):69-78.

CIE, 1976. Colorimetry. Publ. no 15. Bureau Central de la Commission Internationale de I'Eclairage, Vienna, Austria. $14 \mathrm{pp}$.

Gouveia L. and P. Rema, 2005. Effect of microalgal biomass concentration and temperature on ornamental goldfish (Carassius auratus) skin pigmentation. Aquacult. Nutr., 11:19-23.

Gouveia L., Gomes E. and J. Empis, 1996. Potential use of a microalgal (Chlorella vulgaris) in the colouringation of rainbow trout (Oncorhynchus mykiss) muscle. Leben Unter Fors., 202:75-79.

Gouveia L., Rema P., Pereira O. and J. Empis, 2003. Colouring ornamental fish (Cyprinus carpio and Carassius auratus) with microalgal biomass. Aquacult. Nutr., 9:123-129.

Hancz C., Magyary I., Molnár T., Sato S., Horn P. and N. Taniguchi, 2003. Evaluation of color intensity enhanced by paprika as feed additive in goldfish and koi carp using computer-assisted image analysis. Fish. Sci., 69:1158-1161.

Harker M., Tsavalos A.J. and A.J. Young, 1996. Autotrophic growth and carotenoid production of Haematococcus pluvialis in a 30 liter air-lift photobioreactor. J. Ferment. Bioeng., 82:113-118.

Hatlen B., Jobling M. and B. Bjerkeng, 1998. Relationship between carotenoids concentrations and colour of fillets of Arctic charr, Salvelinus alpinus (L.), fed astaxanthin. Aquacult. Res., 29:191-202. 
Hunt R.W.G., 1977. The specification of colour appearance. 1. Concepts and terms. Colour Res. Appl., 2:55-68.

Ingle de la Mora G., Arredondo-Figueroa J.L., Ponce-Polofox J.T., Delos Angeles Barriga-Soca I. and J.E. Vernon-Carter, 2006. Comparison of red chili (Capsicum annuum) oleoresin and astaxanthin on rainbow trout (Oncorhynchus mykiss) fillet pigmentation. Aquaculture, 258:487-495.

Kiriratnikom S., Zaau R. and A. Suwanpugdee, 2005. Effects of various levels of Spirulina on growth performance and pigmentation in goldfish (Carassius auratus). Songklanakarin J. Sci. Technol., 27:133-139.

Miki W., 1991. Biological functions and activities of animal carotenoids. Pure Appl. Chem., 63:141-146.

Nickell D.C. and N.R. Bromage, 1998. The effect of dietary lipid level on variation of flesh pigmentation in rainbow trout. Aquaculture, 161:237-251.

Paripatananont T., Tangtrongpairoj J., Sailasuta A. and N. Chansue, 1999. Effect of astaxanthin on the pigmentation of goldfish Carassius auratus. J. World Aquacult. Soc., 30(4):454-460.

Shahidi F., Metusalach J. and J.A. Brown, 1998. Carotenoids pigments in seafoods and aquaculture. Crit. Rev. Food Sci., 38:339-351.

Skrede G. and T. Storebakken, 1986. Instrumental colour analysıs of farmed and wild Atlantic salmon when raw, baked and smoked. Aquaculture, 53:279-286.

Skrede G., Storebakken T. and T. Naes, 1989. Color evaluation in raw, baked and smoked flesh of rainbow trout (Oncorhynchus mykiss) fed astaxanthin or canthaxanthin. J. Food Sci., 55(6):1574-1578.

Tacon A.G.J., 1981. Speculative review of possible carotenoid function in fish. Prog. Fish-Cult., 43:205-208.

Torrissen O.J., 1995. Strategies for salmonid pigmentation. J. Appl. Ichthyol., 11:276-281.

Tsushima M., Nemoto H. and T. Matsuno, 1999. The accumulation of pigments from paprika in the integument of goldfish Carassius auratus. Fish. Sci., 64:656657.

Wallat G.K., Lazur A.M. and F.A. Chapman, 2005. Carotenoids of different types and concentration in commercial formulated fish diets affect color and its development in the skin of the red oranda variety of goldfish. N. Am. J. Aquacult., 67:42-51.

Vernon-Carter J., Palafox J.T.P. and R.P. Islas, 1994. Bioensayo de pigmentacion de trucha arcoiris (Oncorhynchus mykiss) con extractos de chile ancho (Capsicum annuum). Arch. Lationam. Nutr., 44:252-255.

Vernon-Carter E.J., Ponce-Palafox J.T. and R. Pedroza-Islas, 1996. Pigmentation of Pacific white shrimp (Penaeus vannamei) using Aztec marigold (Tagetes erecta) extracts as carotenoid source. Arch. Latinoam. Nutr., 46:243-246.

Xu X., Jin Z., Wang H., Chen X., Wang C. and S. Yu, 2006. Effect of astaxanthin from Xanthophyllomyces dendrorhous on pigmentation of goldfish, Carassius auratus. J. World Aquac. Soc., 37:282-288. 
Yanar M., Erçen Z., Hunt A.Ö. and H.M. Büyükçapar, 2008. The use alfalfa, Medicago sativa, as a natural carotenoid source in diets of goldfish, Carassius auratus. Aquaculture, 284:196-200.

Yokoyama A. and W. Miki, 1995. Composition and presumed biosynthetic pathway of carotenoids in the astaxanthin-producing bacterium Agrobacterium aurantiacum. FEMS Microbiol. Lett., 128:139-144. 